\title{
BREWING PERFORMANCE OF A YEAST AFTER PROLONGED GROWTH ON A SYNTHETIC MEDIUM
}

\author{
by \\ BJøRN E. CHRISTENSEN and MORTEN C. KIELLAND-BRANDT \\ Department of Physiology, Carlsberg Laboratory \\ Gamle Carlsberg Vej 10, DK-2500 Copenhagen, Valby \\ and
}

KENNETH ERDAL

Department of Brewing Chemistry, Carlsberg Research Laboratory

Gamle Carlsberg Vej 10, DK-2500 Copenhagen, Valby

Keywords: Yeast stability, Saccharomyces carlsbergensis

Two clones of brewers yeast, grown for more than 300 cell generations on a synthetic minimal medium were propagated on wort and used in pilot brewing experiments. Parallel brews with wort cultured yeast were carried out for comparison. Analytical data showed no differences between beer brewed with yeast grown on minimal medium and wort cultured yeast. One out of the two clones grown on minimal medium gave a beer with a somewhat inferior taste.

\section{INTRODUCTION}

Yeast stocks used in beer fermentation are usually maintained either freeze-dried or on complex media (4), and to our knowledge there has been made no study of the brewing performance of yeast that has been grown for a long time on synthetic medium.

We have addressed ourselves to this question, since the development of breeding methods for brewers yeast may at many stages depend on selection for prototrophy on minimal media. It is not evident that prolonged growth on synthetic medium can be done without adverse effects on the brewing performance. The selection pressure may be quite different and result in the selection of unwanted variants formed by mutation or somatic crossing-over.

Here we report on the brewing performance of yeast grown for more than 300 cell generations on synthetic medium. 


\section{MATERIALS AND METHODS}

\subsection{Strain and media}

The yeast was Saccharomyces carlsbergensis, Culture Collection of The Carlsberg Breweries, strain 244. Hopped pilsner wort was obtained from The Carlsberg Breweries. The synthetic minimal medium (5) contained per liter: $1 \mathrm{~g}$ $\left(\mathrm{NH}_{4}\right)_{2} \mathrm{SO}_{4}, 0.875 \mathrm{~g} \mathrm{KH}_{2} \mathrm{PO}_{4}, 0.125 \mathrm{~g} \mathrm{~K}_{2} \mathrm{HPO}_{4}$, $0.500 \mathrm{~g} \mathrm{MgSO}_{4} \cdot 7 \mathrm{H}_{2} \mathrm{O}, 0.10 \mathrm{~g} \mathrm{NaCI}, 10 \mu \mathrm{g}$ $\mathrm{CuSO}_{4} \cdot 5 \mathrm{H}_{2} \mathrm{O}, 10 \mu \mathrm{g} \mathrm{KI}, 50 \mu \mathrm{g} \mathrm{FeCI} \cdot 6 \mathrm{H}_{2} \mathrm{O}, 70 \mu \mathrm{g}$ $\mathrm{ZnSO}_{4} \cdot 7 \mathrm{H}_{2} \mathrm{O}, 0.10 \mathrm{~g} \mathrm{CaCl}_{2} \cdot 2 \mathrm{H}_{2} \mathrm{O}, 2 \mu \mathrm{g}$ biotin, $400 \mu \mathrm{g}$ thiamin, $400 \mu \mathrm{g}$ pyridoxin, $2 \mathrm{mg}$ inositol, $400 \mu \mathrm{g}$ Ca-pantothenate, $20 \mathrm{~g}$ dextrose. Media for plates were solidified with $2 \%$ Bacto agar.

\subsection{Prolonged growth on synthetic medium}

Yeast cells were streaked on synthetic minimal medium, which was incubated at $30^{\circ} \mathrm{C}$ for two or three days. Cells from an isolated colony were transferred to a new minimal plate, and this procedure was repeated 18 times. Assuming at least 18 cell generations for the growth of a single cell into a colony this corresponds to more than 300 cell generations.

\subsection{Propagation}

Propagation for the pilot brewing was carried out by successive inoculations of larger and larger volumes of sterile wort: Ten $\mathrm{ml}$ were inoculated with approximately $10^{6}$ yeast cells; after two days, when fermenting vigorously, the culture was transferred into $300 \mathrm{ml}$ wort, which amount after four days was poured into 12 liter wort and allowed to ferment out ( 5 days). The temperature ranged from $27^{\circ} \mathrm{C}$ at the initial step to $20^{\circ} \mathrm{C}$ at the end of propagation. The temperature was then lowered to $10^{\circ} \mathrm{C}$ to allow the yeast to settle.

\subsection{Pilot brewing}

The pilot experiments were carried out in our pilot brewery (1). For each of the propagated yeast samples $28 \mathrm{~kg}$ portions of hopped pilsner wort ( $10.3 \%$ Plato) were pitched. After fermentation for one week at $10^{\circ} \mathrm{C}$, the beer was racked into a 251 storage tank with $\mathrm{CO}_{2}$ pressure and placed in a refrigerated cabinet.
During 6 weeks of storage, the beer temperature was decreased gradually from $5^{\circ} \mathrm{C}$ to $=1^{\circ} \mathrm{C}$. The beer was filtered through $20 \times 20 \mathrm{~cm}$ Seitz K-7 sheets and the $\mathrm{CO}_{2}$ content adjusted to $0.5 \%$. Bottling and crowning were carried out manually, the bottles being knocked to reduce the air content in the headspace. The bottled beer was pasteurized at $62^{\circ} \mathrm{C}$ for 20 $\min$.

\subsection{Analyses of yeast and beer}

The amount of yeast cells was counted on a Coulter Counter, Model D, and the percentage of dead cells determined with methylene blue.

Beer analyses were done according to ANALYTICA-EBC specifications (2) except for head retention, which was determined after BLom (3).

\section{RESULTS AND CONCLUSION}

The yeast stock was streaked on wort agar, and two isolated colonies were taken for the parallel series of experiments outlined in Fig. 1. After more than 300 cell generations of growth on synthetic medium the yeast was propagated for pilot brewing, as was yeast from the original stock and from the two clones on the wort agar plates.

Since the fermentation temperature during the propagation was higher than that used in lager brewing, the physiological state of the yeast just after the propagation procedure could not be considered representative. In order to obtain a more representative pitching yeast, each of the five propagated yeast cultures was used in an adapting pilot brew and harvested after fermentation for pitching the experimental brew. Beer from the five adapting brews and the five experimental brews was bottled and analyzed. The results from the experimental brews are presented in Table I. The results from the adapting brews turned out to be very similar to these and are not described in detail. At pitching the experimental brews contained between 13 and 20 million cells per ml, of which between 15 and $25 \%$ were scored as dead.

The analytical data of the Table are all within 


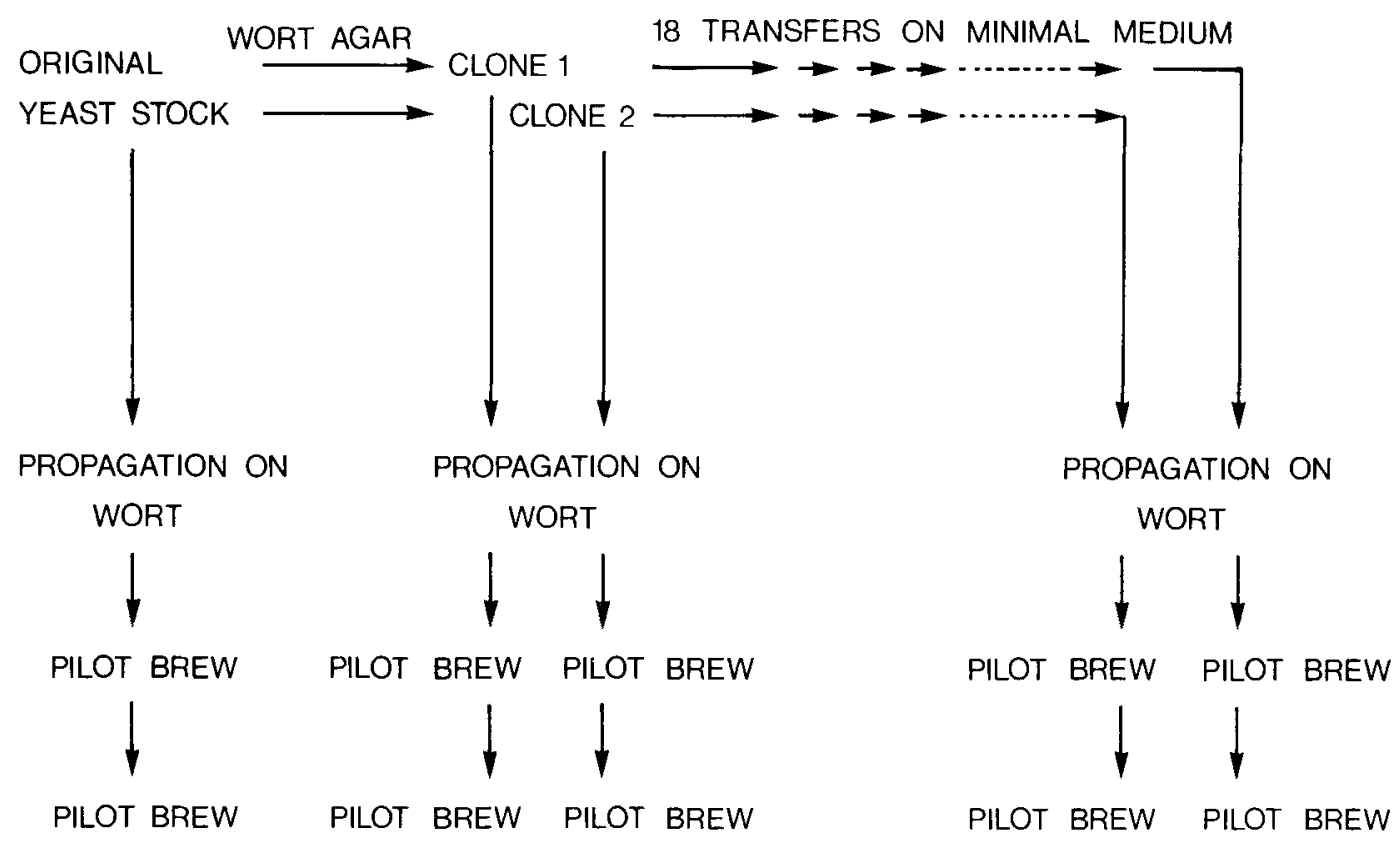

Figure 1. Flow diagram of the experiments.

\section{Table I}

Comparison of pilot brews with Saccharomyces carlsbergensis, strain 244, cultured on different media.

\begin{tabular}{|c|c|c|c|c|c|}
\hline $\begin{array}{l}\text { Analysis of the } \\
\text { bottled beer }\end{array}$ & $\begin{array}{l}\text { Original } \\
\text { stock }\end{array}$ & $\begin{array}{l}\text { Clone I on } \\
\text { wort plate }\end{array}$ & $\begin{array}{l}\text { Clone } 2 \text { on } \\
\text { wort plate }\end{array}$ & $\begin{array}{c}\text { Clone } 1 \\
\text { on minimal } \\
\text { medium }\end{array}$ & $\begin{array}{c}\text { Clone } 2 \\
\text { on minimal } \\
\text { medium }\end{array}$ \\
\hline $\begin{array}{l}\text { Real extract, \% Plato } \\
\text { Alcohol, \% wt. } \\
\text { Attenuation, real \% } \\
\text { Bitterness units } \\
\text { pH } \\
\text { Viscosity, mPa.s } \\
\text { Head retention, } \\
\text { seconds } \\
\text { Diacetyl, ppm } \\
\mathrm{SO}_{2}, \text { ppm } \\
\text { Total } \mathrm{N} \text { mg/l } \\
\text { Flavour profile: }\end{array}$ & $\begin{array}{c}3.81 \\
3.38 \\
63 \\
17 \\
4.2 \\
1.57 \\
\\
80 \\
0.13 \\
11 \\
400 \\
\text { Within } \\
\text { acceptable } \\
\text { range of } \\
\text { pilot brews }\end{array}$ & $\begin{array}{c}3.86 \\
3.24 \\
62 \\
16 \\
4.2 \\
1.55 \\
\\
84 \\
0.15 \\
11 \\
400 \\
\text { Within ac } \\
\text { of pi }\end{array}$ & $\begin{array}{c}3.86 \\
3.28 \\
62 \\
17 \\
4.2 \\
1.55 \\
\\
83 \\
0.13 \\
10 \\
400 \\
\text { ble range } \\
\text { ews }\end{array}$ & $\begin{array}{c}4.07 \\
3.30 \\
61 \\
17 \\
4.3 \\
1.57 \\
\\
87 \\
0.12 \\
6 \\
420 \\
\text { Within } \\
\text { acceptable } \\
\text { range of } \\
\text { pilot brews }\end{array}$ & $\begin{array}{c}3.92 \\
3.44 \\
63 \\
18 \\
4.2 \\
1.57 \\
\\
83 \\
0.16 \\
14 \\
400 \\
\text { Slightly } \\
\text { aberrant } \\
\text { taste }\end{array}$ \\
\hline
\end{tabular}


the usual variation of pilot brews. The taste panel classified one of the beers brewed with the yeast grown on synthetic medium as slightly inferior and the other as normal.

The number of generations of the yeast cells on minimal medium in the present experiments exceeds that which would usually be involved in selection steps during breeding work. The results reveal that prolonged growth on minimal medium need not cause selection for inferior brewing performance. In breeding methods for brewers yeast selection steps on minimal or other synthetic media thus appear acceptable.

\section{REFERENCES}

1. Ahrenst-Larsen. B.: Nyt forsøgsbryggeri på Tuborg (in Danish with English summary). Brygmesteren 24, 109-128 (1967)

2. Analytica-EBC, Analysis Committee of European Brewery Convention, T.-M. Enari ed. Schweizer Brauerei-Rundschau, 3rd ed., Zürich (1975)

3. Blom, J.: Über die Bestimmung der Haltbarkeit des Schaumes. Eu.Brew.Con.Proc.Cong., Copenhagen 1957, 51-56(1957)

4. KIRSOP, B.: The stability of biochemical, morphological and brewing properties of yeast cultures maintained by subculturing and freeze-drying. J.Inst.Brew. 80, 565-570(1974)

5. ZimmermanN,.F. K.: Detection of genetically active chemicals using various yeast systems. In: Chemical Mutagens. Principles and Methods for their Detection. A. Hollaender ed., Plenum Press, New York-London, Vol. III pp. 209-239 (1973) 